\title{
Man and History: Christianity in the system of historical relays and transmissions
}

\author{
Rozaliya Rupova ${ }^{1, *}$, Maxim Bakhtin ${ }^{2}$ \\ ${ }^{1}$ Russian State Social University, Russia \\ ${ }^{2}$ Encyclopedist-Maximum
}

\begin{abstract}
Under the conditions of crisis and catastrophic events of the 20th century, a significant deepening of historiosophical thought took place, and attempts to create explanatory models of the historical development of society intensified. In the third millennium of the Christian era, new problems have already accumulated, requiring a new awareness of the culture-forming role of Christianity in modern conditions. Questions of understanding the historical process have been raised for many centuries, but at the present stage they are posed anew. A new perspective has appeared in the topic of comprehending history - the theology of history. In the tradition of Russian religious philosophy, it is associated with the names of N. Berdyaev and - especially - G. Florovsky. To this issue has been paid attention; new publications have been included. In addition, other approaches to understanding the historical process are considered in the work. The authors focus on the Christian tradition as a system of sociohistorical relay races and broadcasts and the proposed systematic understanding of a person in his being in history and culture as part of this tradition. It is also shown that tradition as a historical phenomenon often becomes an object of ideological and political speculation and needs protection.
\end{abstract}

\section{Introduction}

Crises and catastrophes of the twentieth century have influenced a significant deepening of historiosophical thought, has intensified the creation of many models of the historical development of society. As N.A. wrote Berdyaev, "historical catastrophes and faults have always contributed to reflections in the field of philosophy of history, attempts to comprehend the historical process, to build this or that philosophy of history" ("Sense of history).

For many decades of the twentieth century, the leading position in Soviet historical science has been captured by such an understanding of history, according to which it appears as an arena of impersonal social forces, undivided domination of hard determinism, a "historical necessity" that prescribes appropriate thoughts and actions to people that are independent of their will. Textbooks have been flooded with terminology such as "the phase of economic growth", "the stage of social development", etc.

\footnotetext{
*Corresponding author: rozaliya-rupova@yandex.ru
} 
Historical materialism, which has every right to exist as one of the theories of the historical process, reigned supreme over minds, avoiding dissent, claiming the only true understanding of human history. History was depersonalized, the names of people were present in it, rather as symbols of certain historical trends than as living individuals with their thoughts and destinies. However, this does not mean that in the real historical process there are no objective laws.

Christianity had a radical influence on historical consciousness as such and on historiosophy. "Only the establishment of Christianity as the dominant religion of Europe in the 4th century gave rise to the historicalization of cultural consciousness in its specific European sense. Only starting with Christian historiosophy, we have the right to talk about a full and developed philosophy of history" (Bakhtin M.V. "Theological Understanding of History"). According to biblical revelation, God is the creator of not only the world, but also time itself. The world has a beginning and an end. The first book of scripture - the Book of Genesis - tells the beginning of the world, the beginning of history. The last book - The Revelation of St. John the Theologian - paints a picture of the Apocalypse, the end and fulfillment of history, the end of time as such. Between these two points, and according to the Christian view, the entire historical process takes place. It is fundamentally important to note that the Apocalypse reveals the meaning of history that goes beyond the boundaries of earthly existence, that is, having a transcendental character. Thus, Christian history is not just a directed process from the point of beginning to point of end - it has a pronounced teleological character, that is, it has a purpose and meaning. Schools of the Eastern tradition claimed the dualism prevailing in it as a characteristic of this world - the presence of two equal principles: Good and Evil, Light and Darkness, Cosmos and Chaos, Yang and Yin, which are in constant opposition. Biblical metaphysics affirms the principle ontological monism as the most important characteristic of this world, which means the existence in the world of only one positive creative force - God, who created the world from nothing (ex nihilo).

The question of the existence of evil does not cease to be debated throughout the history of the human race. The biblical doctrine of evil does not endow it with an essential, but existential status. "Ontological monism, which affirms the original unity of being, namely, Absolute Being, fundamentally undermines pagan ideas about the substantiality of evil - the second, dark, negative ... beginning of the world (that manifested in Manichaean teaching). Evil in the Bible, unlike oriental and ancient teachings, does not have an independent ontological status. It is not an essence, it is only an existence. Independent Substance is only Good and Love - the Lord God. Unlike pantheism, which identifies God with nature, biblical teaching speaks of the presence of two ontologically different natures: divine and created. Among the created, angels and people have the freedom to choose between good and evil. Evil is the direction of the will against God. This fundamental principle of free will is the foundation of the Christian philosophy of history. If we turn to the patristic heritage, in particular, to the writings of the great theologian and hymnographer of the eighth century John Damascene, then we will find a comparison of two positions in his views on human fate - pagan and Christian: "The Greeks, of course, say that through climbing and setting, and the rapprochement of stars and the sun, and the moon, all our affairs are arranged; for astrology does this; however, we affirm that, although they give the omens of rain and no-rain, both cold and heat, both humidity and dryness, this in no way an omen of our affairs. For we, descended from the Creator gifted with free will, are the masters of our affairs. For if we do everything as a result of the flow of stars, we do what we do when necessary, and what happens when necessary, is neither virtue nor vice; if we have neither virtue nor vice, then we are not worthy of praise or punishment, and God will also be unjust, delivering for ones good and for others distress. But God will not even rule over His creations, nor construct the fates of them, if everything is controlled and carried away by necessity. Moreover, the mind 
will be superfluous in us, for we, being masters of no business, think too much about ourselves; but reason is certainly given to us for discussion, why to everything rational is also gifted with free will ... voluntary is that which is the beginning, that is, when the reason is in the doer, who knows everything separately, through which the action takes place" ("John of Damascus. Exact statement of the Orthodox faith"). As N.A. wrote Berdyaev, "if there had not been freedom, there would have been no history. Freedom is the metaphysical fundamental principle of history" ("The meaning of history").

The anthropological foundation of the Christian philosophy of history also includes the concept of the status of man in universe. If the Greeks understood him as a "microcosm", then we can say that in the biblical tradition a person is rather a "micro-God" by virtue of his creation "in the image and likeness" of God. That is, "the ontological status of man in Christian anthropology is higher than the status of the cosmos and everything that it contains. This means that man is the center, meaning and purpose of the whole universe, of all history. " The Christian idea of the uniqueness of the human person, the uniqueness of the event of the incarnation of God gives the whole story a deeply personal character. As N.A. wrote Berdyaev, "singleness and non-repeatability is the main feature of the whole "historical" ("The meaning of history"). The fact of the incarnation of God is a unique event of the union of the temporal and eternal, divine and created natures in one Person. This was the revelation of God in history, which determined the historicity of Christianity. "The whole world history directed to this unique central fact, and all history goes from it." ("The meaning of history"). The messianic idea, which was the pivot of the historical existence of the Jewish people, "straightened history" by unrolling the ring of the cyclic model of pagan antiquity. Here is a view of the historical process, which is organic for the Christian consciousness: "Through all days and nights, all people, and with them the whole nature, hurry to the last day, in which the mystery of this world and the history of human will be end ... And how at the end of the creation of the Lord made an inspection of all creatures and things created by Him, and pronounced His judgment on everything, so on the last day He will make a review of all beings and things at the end of their journey through history and will render His infallible judgment on everything “ (Justin (Popovich) "Dogma of the Orthodox Church: Eschatology").

The anthropological foundation of Christian philosophy of history is the idea of the unity of mankind. The Jews raised their kinship from a single ancestor - Adam. Christianity affirms the consanguinity of the entire human race. And not only kinship. Preaching His teachings, according to the last commandment of Christ, to all nations, Christianity thus realized the semantic unity of mankind, transforming it into a single cultural community.

We can say that Christianity set not just history, but meta-history, where its earthly segment is part of a drama of a universal scale that goes beyond the limits of the local being of the human race. According to the Christian model of the historical process, two forces act in history, two wills - Divine and human. In other words, the whole story is a God-human process. Moreover, with regard to man, his historical being, as a result of the fall, is characterized by tragic instability, loss, incompleteness of knowledge of the meaning of his existence. God possesses the fullness of historical knowledge - the Creator and Provider of the fate of the world. An important place in the Christian philosophy of history is occupied by the doctrine of the Providence of God. The providence of God is a divine activity in world life, preserving the world and directing it to the purpose of life intended for it, by the ceaseless action of the omnipotence, wisdom and goodness of God, by which the Lord preserves the being and strength of creatures, directs them to good ends, contributes to all good, and an evil, arising through removal from good, He suppresses and turns it to good consequences. In this case, the real driving force of history is a person with free will. 


\section{Materials and methods}

Defining society as "a dynamic system capable of changing the forms of its economic, social, political, spiritual organization", it should be borne in mind that the study of this system by means of social philosophy and sociology will inevitably involve the consideration of the most general laws of changes in the forms of social organization (about these laws were written both by K. Marx and Pitirim Sorokin), and a comparison of the methods of social transformation (for example: evolutionary and revolutionary), etc. In this case, the study uses a modeling method in which there is an abstraction from the concrete historical properties of a society, its geographical, cultural, political, ethnic, and other characteristics. But any modeling always implies taking into account the error that distinguishes the model from the real process, dry theory - from the greening "tree of life". History is characterized by the concreteness of its manifestations; All the eternal problems of human existence can be considered only on concrete historical material, in real time and space. History can be defined as the scope of individual events in which they exist and in which the general and special features of social organization are manifested. Just like a society, in the study of which different levels of consideration of social structures are possible, history studies the same reality that appears to us as "social life". The framework of history in the process of its existence from ancient chronicles to the present day has continuously changed its position: they often narrowed, including only especially important events that fit the rank of "historical", then, neglecting the level of "everyday life", described the "heroic", or associated exclusively with the life of the "Caesars". Obviously, with this understanding of history, the possibility of arbitrariness in determining the status of events that are suitable or not suitable in order to enter the list of historical events is created. The only way to avoid such a situation is to recognize that history is an integral stream of events in public and private life, covering the entire spectrum of human existence without exception, without splitting into "important" and "not important", "interesting" and "not very". We note one significant point. One can see a contradiction in the fact that history, claiming to be a metatheory, would seem to have a high degree of abstractness. But in this case, the exact opposite happens - being interested in the "structures of everyday life", in chronologically "the flow" of people's lives, history, like no other science, turns out to be far from abstractions.

This contradiction can be classified as "dialectical," which, however, will not bring additional clarity, since the entire historical process is materialized dialectics. The resolution of this contradiction is possible when moving to a different level of consideration - the level of philosophical reflection within historical science itself - that is, the very level where history merges with social philosophy. It is at this level of consideration that one can speak of history as a "metalogy for all logic, a court with an infinite number of cassations" (A. Dorogov).

\section{Discussion}

Issues of understanding the historical process have been raised for many centuries. In the twentieth century, these topics were re-posed. A new perspective has appeared - the theology of history. This topic in the tradition of Russian religious philosophy is connected with the names of N. Berdyaev and - especially - G. Florovsky, whose contribution to this semantic field can hardly be overestimated. In the third millennium, a number of authors joined in this topic. We can call the system studies of S.S. Horujy [1,2,3] and of the school he created in a wide thematic spectrum of the spiritual tradition of Christianity. The theology of history is purposefully developed in the works of Legeev M.V. [4,5,6]. A number of studies are devoted to understanding the Christian tradition in historical and anthropological aspects. We will name a number of authors who have contributed to the development of this problem field: 
Chursanov S.A. [7], Mikhailov P.B. [8], Solonchenko A.A. [9,10], Mahler A.M. [11], Fufaev S. [12]. Studies by authors of this article have also been carried out in the same direction $[13,14,115]$. Modern aspects of studying the Christian tradition are reflected in the studies of Western scholars - world famous and just beginning to develop this topic: Ware K. [16] Nesteruk A.V. [17].

In the work "Theological Comprehension of History" M.V. Bakhtin carries out this task on a wide historical perspective: "Herodotus, Thucydides, Xenophon, Plato created their historical works and constructions in the era of the collapse of the ancient polis, slavery. The theological and historical model of St. Augustine dates back to the collapse of the ancient world and the fall of Rome. Oswald Spengler wrote his landmark work "The Sunset of Europe", in 1918, during the collapse of the old, monarchical world. Russian philosophy of the history in the epoch of spiritual renaissance of the turn of the nineteenth and twentieth centuries is no less vivid confirmation of this thesis. The philosophical and historical thought is experiencing the same moment today" ("Theological Comprehension of History").

The catastrophic history of the twentieth century gave rise to a crisis of historicism and, as a consequence, an intensification of eschatological themes in different versions ("end of history", "posthistory", etc.). The dominant trend of philosophical and historical thought was anti-historicism. The extraordinary complexity of the social dynamics of the 19th -20 th centuries, the "unmodelability" of social processes gave rise to the idea of the absence of historical determinism between eras, the impossibility of explaining each historical period from the previous one. Truly, according to Hamlet, "the connection of time has broken up". In 1918, Oswald Spengler in his book "The Sunset of Europe" offers his own model of history. He identifies eight great cultures, replacing one another, but existing completely independently. Rejecting "Newtonianism" with its Laplacean determinism in a historical perspective, he creates a picture in which each era is unique, like a rare plant: "humanity has no goal, no idea, no plan, just as have no goal of butterflies or orchids. "Humanity" is an empty word. <...> Instead of a monotonous picture of a linearly-shaped world history, one can hold on to it only by turning a blind eye to the overwhelming number of facts contradicting it, I see a phenomenon of many powerful cultures, $<\ldots>$ each of them imposes its own form on human material - and each has its own idea, own passions, own life $<\ldots>$ and own death. <..> These cultures, living beings of a higher order, grow with their exalted aimlessness, like flowers in a field. Like plants and animals, they belong to Goethe's wildlife, and not to Newton's world nature" ("The Sunset of Europe") . Consonant with the approach to the history of O. Spengler, that protesting against historical dogmatism, is the creative development of the philosophy of history A. Toynbee (1889-1975). He can be attributed to religious thinkers. He argues with sociocentric ideas that became widespread in the 19th 20th centuries, actively attracting analogies from the physics that was experiencing its upsurge during this period: "Space itself, without committing actions, is the sphere of action of electrons, atoms, particles, and society cannot play an active, creative role in human affairs. Society is and cannot be anything other than a mediator through which individuals interact with each other. Individuals, not societies, create human history" (Toynbee A. J. "Understanding History").

The refusal of many representatives of twentieth-century historiosophical thought to seek historical determinism, a universal meaning, the connection of historical eras is a characteristic feature of Western historiosophy. There is no doubt the influence of F. Nietzsche, whose ideas dealt a tangible blow to traditionalism in approaches to culture and history.

The Christian tradition included in the coordinates of the global historical process, it offers a systematic understanding of man in history and culture. In the third millennium of the Christian era, new problems have already accumulated, requiring a new awareness of the culture-forming role of Christianity in modern conditions. "Modern European culture arose 
from Christianity, which created cultural forms of organizing life, using for this not only the experience of the Old Testament, but also the richest Greek and Roman culture of social organization, philosophical thought, and artistic creation. The history of Europe is a long process of Christianization of all areas of culture, the cultural heritage of peoples" [ Schreider J. "Christ - the source and foundation of a new European culture"].

Among the many definitions of culture, there are such: "culture is a system of social relay races in which participants pass role models to each other". This definition indicates the existence of a broadcasting tradition and implies the cognitively significant nature of broadcast content. The most important function of culture is that it expresses the meaning of human existence. The concept of meaning also requires clarification. The meaning is described in a certain sign system. Through the efforts of the Cappadocian Fathers of the Church, cultural forms corresponding to their era (4th century) became carriers of Christian meanings. They actively transform the tradition of pagan Neoplatonism. Subsequently, in the West, Thomas Aquinas, in the words of G.K. Chesterton, "christened Aristotle," using Aristotle's philosophy as a tool for a expression of Christian theology.

We can say that culture requires from the creed to make efforts to convey the Christian meaning by means of cultural forms. In our era, this requirement takes on special significance: either destructive meanings will prevail in culture (and with modern means of disseminating information, they will quickly produce widespread destructive effects), or it will become a carrier of high Christian morality and will serve as a spiritual healing and pacification of society.

\section{Results}

On the cultural field of our time, a great polyphony and a great variety of forms unfold before us. This, on the one hand, as if, testifies to the magnificent flowering of culture. But, if you look closely, we will see thousands of print runs of mass culture products: dubious photos and film production of various formats, virtual gaming worlds with their special destructive aesthetics, permissiveness and omnivorousness of advertising, and much more that the Internet gushes.

These phenomena are usually contrasted with the concept of tradition. But we are offered a whole assortment of certain traditions that are invented bypassing historical science; they are overgrown with mythology, gaining many adherents. Obviously, the very concept of tradition is rather vague and requires clarification and conceptualization. Such phrases as "spiritual heritage" or "spiritual tradition" are often nothing more than journalistic cliches, and not at all historical and cultural terms. Only by clarifying this basic concept can one then conceptualize culture in these coordinates. The etymological reading of the word "tradition": traditio or tradition (transmission) allows us to see the transmission mechanism as the main one, as "a transmission mechanism in historical time and human society, as a social or cultural institution that carries out storage and transmission, broadcasting of a certain fund, heritage, values, attitudes, etc." [S.S. Horujy. "Experiences from the Russian spiritual tradition"]. This key mechanism forms the connecting basis of the historical process.

S.S. Horujy, as the defining characteristic of a particular tradition, identifies two main classification features: the content of transmission and the method of transmission. With their help, you can consider the existing traditions.

Consider the spiritual tradition of Christianity in these coordinates. The content that she broadcasts is the event of Christ in the fullness of his mission and teaching, accumulated in the mystical and ascetic experience of the Eastern Church. The method of transmission is personal communication, "from mentor to student." Spiritual tradition is a "personal, energetic, anthropological phenomenon" [S.S. Horujy. "Experiences from the Russian 
spiritual tradition"]. Its uniqueness is manifested in the fact that without creative efforts its preservation and transmission are impossible.

Maintaining the identity of spiritual experience during such epochs that are so far apart in time and radically differing in the mentality of culture and anthropological realities is possible exclusively creatively. Around the spiritual tradition, a religious tradition is being builtas a broader one. The transmission content is much more diverse and variegated - this is the material forms of worship, and institutional structures and religious behavioral stereotypes. The method of transmission is also very diverse - through ritual forms, religious institutions. And although the core of a religious tradition is spiritual practice, by its nature a religious tradition is a social phenomenon.

Cultural tradition can be considered as a whole vast complex of traditions with different content and methods of transmission. These are "cultural monuments", scientific, professional and philosophical schools, a combination of art forms, ethical standards, etc. Forms of transmission are mainly institutional and collective. Cultural tradition is inherently a social phenomenon. Pedagogy is one of the leading systems of social transmission. An interesting specificity of the cultural tradition is the fact that, unlike the spiritual tradition, where creativity is an indispensable condition for its storage and transmission, here creativity is in going beyond the limits, creating new forms. Cultural tradition can be associated with a spiritual tradition, focus on it, act as an adjoining one. Cultural tradition is part of an extremely broad social tradition that inherits social institutions as such.

One more class can be distinguished - folk traditions. This is a complex and heterogeneous form of social life. The transmissing material is the archaic strata of ethnocultural consciousness, often manifesting themselves as a "collective unconscious". It is also a social phenomenon and a mode of transmission - also an impersonal, social one.

The mutual interweaving of all these traditions forms the historical life of society. Each of the traditions codifies a kind of anthropological identity. The spiritual tradition in this case occupies a special position. Identity, the proclaimed in spiritual tradition of Christianity, determines the theocentric anthropological paradigm, due to the creating of man "in the image and likeness of God." In other traditions, identity is built in accordance with one or another sociocultural form that belongs to the this world. Therefore, the person in them is reduced, being presented, for example, as a social subject.

In history are known Epochs when the spiritual tradition of Christianity had a colossal and leading influence on the life of society - the entire Byzantine period, the European Middle Ages, pre-Petrine Russia. In other periods the affecting on society was more indirectly, through various socio-anthropological practices. In this case, the spiritual tradition, as focused on personal experience and building ontologically stronger relationships - the relationship between man and God, affecting the deepest spheres of human existence, acts as the leader, and the other (for example, cultural tradition) - as adjacent - not always in its entirety, possibly in the form of individual schools and directions.

This situation is very productive for culture. For example, the language of the image became organic for the Church after the Incarnation, but acquired the character of a mass phenomenon due to the synergy of cultural, religious and spiritual traditions. Here is the testimony of an art historian: "[In the Middle Ages - RR] a person comprehends the Good News and tries to feel into it. Art creates a unique language - the language of an icon - capable of telling about the inexpressible, revealing the invisible" [Ratner L.N. "In search of the meaning of beauty"]. That is, fine art, being the living language of the cultural tradition inherited from Antiquity, carried out a powerful impulse toward the spiritual tradition, solving the tasks of God-knowledge by its own means.

\section{Conclusions}


The interrelations of traditions are important for a characteristic of society. As was shown, in the Middle Ages, the cultural tradition was adjacent and even subordinate to the religious tradition. In the Renaissance, they come into conflict and, not breaking with the religious tradition, the cultural tradition ceases to be adjacent to the spiritual, breaks with it. In modern times, the spiritual tradition is supplanted on the periphery of social life, and the cultural tradition becomes dominant. During this period, a remarkable transformation of theology takes place in the West. It also loses touch with the spiritual tradition. Theology in the West continuing to exist in the educational system as a science, that is, as part of the cultural tradition.

If we look at domestic history in the coordinates of relations between cultural and spiritual traditions, we will see a path full of drama and acute conflicts. In modern Russia, the word "tradition" has become a key word in many ideological or political models. We can refer to them Byzantism, idealizing the Byzantine imperial system, neo-Eurasianism, Rodnoverie. These are simulacra of traditions. "Traditionalism in Russia today is a very significant component of the ideological and political situation ... he either makes a certain construct, releasing it under the name of the proto-tradition, or manipulates any real tradition, fitting it into a certain project, political, ideological or religious" [S.S. Horujy. "Experiences from the Russian spiritual tradition"].

Traditionalism as a phenomenon, in its individual forms, most consistently deviating from objective scientific research, is characterized by one common feature - the postulation of some archaic time, a proto-tradition that justifies the pseudocultural forms created today pagan or nationalistic. In the presence of a certain romanticization, attractiveness, the driving motives of these projects are usually political, geopolitical, ideological goals and plans external to them. Their creators and apologists certainly affirm by the "scientific proofs" the historicity of their products.

German fascism relied on such a pseudo-tradition, as an Arianism. In modern radical Islam, there is a Salafiiyah, whose task is to return to the original Islam of the time of Mohammed. And this is not the only version of the ideological constructions of modern Islamic extremism. Russian neopaganism, preaching the revival of the cult of the gods of the ancient Slavs, appealing to it as an organic proto-tradition for Russia, not only opposes Orthodoxy, but is also a breeding ground for nationalism.

You can add to this an eschatologism, which, with various accents for many centuries of Russian history, "controls the future" - in contrast to the above forms of manipulation of the past.

Thus, it is obvious that tradition is an object of ideological and political speculation and needs to be protected. Supporting the most seemingly innocent and noble pseudo-traditions, without regard to their historical reality, leads to an apology of ignorance and to the fact that extremist ideologemes can become the property of the masses.

A counterweight to the manipulation of tradition is life in the true spiritual tradition of Eastern Christianity, its creative reading in the spirit of the neo-patristic synthesis proclaimed by G. Florovsky, an introduction to the personal experience of the Communion of God.

\section{References}

1. S.S. Horujy, Philosophy and Culture 5, 721 - 729 (2016) DOI: 10.7256/19992793.2016.5.18812

2. S.S. Horujy, Culture and art 1, 25 - 40 (2016) DOI: 10.7256/2222-1956.2016.1.16838

3. S.S. Horujy, Philosophy and Culture 2, 268 - 274 (2016) DOI: 10.7256/19992793.2016.2.16982 
4. M.V. Legeev, S.A. Zinkovsky, E.A. Zinkovsky, Christian reading 4, 10-27 (2018) DOI: $10.24411 / 1814-5574-2018-10078$

5. M.V. Legeev, Christian reading 5, 51-61 (2018) DOI: 10.24411/1814-5574-2018-10107

6. M.V. Legeyev, Proceedings of the Department of Theology of the St. Petersburg Theological Academy 1(2), 208-221 (2018) DOI: 10.24411/2541-9587-2018-10012

7. S.A. Chursanov, Theological Bulletin 1(26), $77-97$ (2020) DOI: 10.31802/2500-14502020-36-1-77-97

8. P.B. Mikhailov, Bulletin of the Orthodox St. Tikhon Humanitarian University. Series 1: Theology. Philosophy. Religious studies 71, 50-68 (2017) DOI: 10.15382/sturI201771.50-68

9. A.A. Solonchenko, Questions of theology 1(1), 30-43 (2019) DOI: 10.31802/26587491-2019-1-1-30-43

10. A.A. Solonchenko, Social policy and sociology 17.3(128), 119-125 (2018) DOI: $10.17922 / 2071-3665-2018-17-3-119-125$

11. A.M. Mahler, Notebooks on conservatism 3, 131-138 (2019) DOI: 10.24030/240925172019-0-3-131-138

12. S. Fufaev, Theological Bulletin 35(4), 38-71 (2019) DOI: 10.31802/2500-1450-201935-38-71

13. R.M. Rupova, Social policy and sociology 17.2(127), 186-193 (2018) https://doi.org/10.17922/2071-3665-2018-17-2-186-193

14. R.M. Rupova, Social policy and sociology 17.3(128), 111-118 (2018)DOI: 10.17922/2071-3665-2018-17-3-111-118

15. R.M. Rupova, Prospects for science and education 2(44), 171-178 (2020) doi:10.32744/pse.2020.2.14

16. K. Ware, International journal for the study of the Christian Church 11(2-3), 216-235 (2011) DOI: 10.1080/1474225X.2011.603975

17. A.V. Nesteruk, Journal of the Siberian Federal University. Series: Humanities 9(9), 2150-2183 (2016) DOI: 10.17516/1997-1370-2016-9-9-2150-2183 